\title{
Properties of Welded Joints on Superheater Coils Made from New Generation High Alloy Martensitic Steels Connected to Austenitic Creep-Resisting Steels and Supper Alloy Grades, for Supercritical Parameters
}

\author{
Jerzy Pasternak ${ }^{1}$, Janusz Dobrzański \\ ${ }^{1}$ Boiler Engineering Company RAFAKO S.A., 47-400 Raciborz; 33 Lakowa Str; Poland \\ 2 Institute for Ferrous Metallurgy, 44-100 Gliwice, 42 K. Miarki; Poland \\ jerzy.pasternak@rafako.com.pl ; jdobrzanski@imz.gliwice
}

Key words: welding, technological and mechanical properties, steel structure stability, corrosion and creep resistance.

\begin{abstract}
The continuously developing power generation sector, including boilers with supercritical parameters, requires applications of new creep-resistant steel grades for construction of boilers steam superheater components. Therefore, this paper contains selected information, results of the research and implementation process including:

- evaluation, comparison of requested properties of base material and welded joints, such as tensile strength, impact strength and technological properties,

- destructive examinations with evaluation of welded joints and HAZ structure and hardness distribution,

- influence of manufacturing process in large boilermaker conditions and after simulated operation.

A new creep-resistant steels to be used, in order to comply with the operational requirements, as to assure the appropriate reliability and safety of the boiler equipment in operation process.

This document presents a simplified analysis of martensitic steels from group 9-12\% Cr (T91, T92, HCM12A, VM12) and austenitic steels Cr-Ni (TP347FG, SUPER 304H, HR3C), having the chemical composition as presented in tables 1 and 2, which are to be applied for steam superheater components.
\end{abstract}

\section{Introduction}

The boilers of supercritical working parameters and the requested low emission level of harmful substances into the atmosphere, require higher and higher outlet steam parameters. Any increase of those parameters necessitates a search for and application of new materials, having higher strength parameters and more complex technological manufacturing process for boiler pressure part components, made of such materials [1-3].

Among the critical boiler pressure parts superheater components play a vital role. They have been elaborated as the result of grade scale research works, mainly within the European programmes COST 511, 522 and COST 536, where steel making, welding materials developments and manufacturing technologies have been worked out with the objective to make boiler components of them [1-3]. The materials of the fabricated boiler components have their material and welded joints characteristics created, so as to obtain knowledge on their behaviour in operating conditions.

\section{Selection of Materials for Steam Superheater Coil Components}

Owing to their operational conditions, live steam and reheat steam superheater coils belong to the most "critical" components of modern power boilers. The creep-resisting steels, which are used for superheater components in the "typical" power units having supercritical parameters, steam temperature of approx. $600^{\circ} \mathrm{C}$, and steam pressure of approx. $30 \mathrm{MPa}$, with steam reheat in the reheat part up to $610^{\circ} \mathrm{C}$, have to assure adequate creep resistance and heat resistance at the temperature, which reaches: 
- $600(610)^{0} \mathrm{C}$ - for boiler thick-walled components located outside the flue gas zone. The thickwalled collectors and steam pipelines unheated by flue gases are made of martensitic steels, having approx. $9-12 \% \mathrm{Cr}$,

- $640(650)^{0} \mathrm{C}$ - for steam superheater components (coils) located in the flue gas zone. The thinwalled steam superheater coils, located in the flue gas environment and made of

martensitic steels, having approx. $12 \% \mathrm{Cr}$ and austenitic steels, having approx. $18-25 \% \mathrm{Cr}$, as well as nickel superalloys which are to be applied [4].

The calculation results of wall thickness on an exemplary live steam outlet superheater for the following assumed design parameters: design pressure e.g. $30 \mathrm{MPa}$, design temperature $630-640^{\circ} \mathrm{C}$ (at the steam medium temperature of $600^{\circ} \mathrm{C}$ ) and the tube internal diameter e.g. $30 \mathrm{~mm}$, have shown that the acceptable wall thickness at these parameters can only be achieved with austenitic steel grades TP347HFG, SUPER 304H and HR3C.

The analysis in question shows that the application of martensitic steels, i.e. in $640(650)^{0} \mathrm{C}$ having the content of $12 \% \mathrm{Cr}$, for the steam outlet superheater coils, results in the tube wall thicknesses which are above the technologically acceptable maximum of $10 \mathrm{~mm}$.

However, the practice which has been followed so far shows that with the aforementioned exemplary steam parameters the requirements set for live steam and secondary steam collectors are met by steel P92 [1,4].

The stress values, which are admissible for steels such as VM12, TP347FG, SUPER 304H, as well as HR3C, are included in the following documents: standard EN 10216-2, VdTÜV-WB, ASME CODE, SA213, part IIA and material specification for V\&M (WBL-439).

\section{Martensite and Austenitic Steels To Be Examined}

Steels $9-12 \% \mathrm{Cr}$, in "as delivered" condition, undergo normalisation (hardening) in air and hightemperature tempering afterwards. The recommended austenitising temperature for those steels has been determined at the level of approx. $1050^{\circ} \mathrm{C}$, whereas the tempering temperature has been established at the range of $740-780^{\circ} \mathrm{C}$. The main structure of $9-12 \% \mathrm{Cr}$ steel is tempered martensite with separated carbides on the grain boundaries of the former austenite and martensite strips, frequently with little presence of ferrite $\delta$. The chemical composition of the collector material to be tested is in compliance with standard EN 10216-2, which has been confirmed on the basis of the testing analyses. Tube test pieces have been provided by V\&M, as the contribution within the European international co-operation programme COST536 [2,3]. The required chemical compositions of the new high-chromium creep-resisting steels, having the martensite structure, which are intending to be used in the Polish power sector for boilers having supercritical parameters, have been collected in Table 1, and the required chemical compositions of austenitic steels have been collected in Table 2 .

Table 1. The required chemical compositions of the new high-chromium creep-resisting steels, having the martensite structure.

\begin{tabular}{|c|c|c|c|c|c|c|c|c|c|c|}
\hline \multirow{2}{*}{ Steel grade } & \multicolumn{10}{|c|}{ Chemical composition, in \% } \\
\hline & $\mathrm{C}$ & $\mathrm{Si}$ & $\mathrm{Mn}$ & $\mathrm{Cr}$ & $\mathrm{Ni}$ & Mo & V & $\mathrm{W}$ & $\mathrm{Nb}$ & Others \\
\hline $\begin{array}{c}\text { X10CrMoVNb9-1 } \\
\text { (T/P91); } \\
\text { W-1.4903 }\end{array}$ & $\begin{array}{c}0.08- \\
0.12\end{array}$ & $\begin{array}{l}0.20- \\
0.50\end{array}$ & $\begin{array}{c}0.30- \\
0.60\end{array}$ & $\begin{array}{c}8.0- \\
9.5\end{array}$ & $\begin{array}{c}< \\
0.40\end{array}$ & $\begin{array}{c}0.85- \\
1.05\end{array}$ & $\begin{array}{c}0.18- \\
0.25\end{array}$ & - & $\begin{array}{c}0.06 \\
- \\
0.10\end{array}$ & $\mathrm{~N} 0.03-0.07$ \\
\hline $\begin{array}{c}\text { X10CrWMoVNb9-2 } \\
\text { (T/P92) }\end{array}$ & $\begin{array}{c}0.07- \\
0.13\end{array}$ & $<0.5$ & $\begin{array}{c}0.30- \\
0.60\end{array}$ & $\begin{array}{l}8.5- \\
9.5\end{array}$ & $\begin{array}{c}< \\
0.40\end{array}$ & $\begin{array}{c}0.30- \\
0.60\end{array}$ & $\begin{array}{l}0.15- \\
0.25\end{array}$ & $\begin{array}{l}1.5- \\
2.0\end{array}$ & $\begin{array}{c}0.04 \\
- \\
0.09\end{array}$ & $\begin{array}{c}\text { N } 0.03-0.07 \\
\text { B } 0.001-0.006\end{array}$ \\
\hline $\begin{array}{c}\text { X12CrCoWVNb12-2-2 } \\
\text { (VM12) }\end{array}$ & $\begin{array}{l}0.11- \\
0.14\end{array}$ & $\begin{array}{l}0.40- \\
0.60\end{array}$ & $\begin{array}{c}0.15- \\
0.45\end{array}$ & $\begin{array}{l}11.0- \\
12.0\end{array}$ & $\begin{array}{c}0.20- \\
0.40\end{array}$ & $\begin{array}{c}0.20- \\
0.40\end{array}$ & $\begin{array}{l}0.20- \\
0.30\end{array}$ & $\begin{array}{l}1.30- \\
1.70\end{array}$ & $\begin{array}{c}0.03 \\
- \\
0.08\end{array}$ & $\begin{array}{c}\text { Co: } 1.40-1.60 \\
\mathrm{~N}: 0.030-0.070 \\
\mathrm{~B}: 0.0030- \\
0.006\end{array}$ \\
\hline
\end{tabular}


Table 2. The chemical compositions of selected new high-chromium creep-resisting steels, having the austenitic structure, expected to be used in Polish Power Generation Sector.

\begin{tabular}{|c|c|c|c|c|c|c|c|c|c|c|c|}
\hline \multirow[b]{2}{*}{ Steel grade } & \multicolumn{11}{|c|}{ Chemical composition, in \% } \\
\hline & $\mathrm{Fe}$ & $\mathrm{Ni}$ & $\mathrm{Cr}$ & Mo & Co & $\begin{array}{c}\mathrm{Nb}^{+} \\
\mathrm{Ta}\end{array}$ & $\mathrm{Nb}$ & $\mathrm{Ti}$ & $\mathrm{N}$ & $\mathrm{Mn}$ & C \\
\hline $\begin{array}{l}\text { X8CrNi19-11 } \\
\text { (Super 304H) }\end{array}$ & $\mathrm{Bal}$ & $\begin{array}{l}9,0- \\
13,0\end{array}$ & $\begin{array}{l}17,0- \\
20,0\end{array}$ & & & $\begin{array}{c}8 \mathrm{xC}- \\
1,0\end{array}$ & & & & $\begin{array}{c}\max \\
2,0\end{array}$ & $\begin{array}{c}0,06- \\
0,10\end{array}$ \\
\hline $\begin{array}{c}\text { X6CrNiNbN25-20 } \\
\text { (HR3C) }\end{array}$ & $\mathrm{Bal}$ & $\begin{array}{l}17,0- \\
23,0\end{array}$ & $\begin{array}{l}23,0- \\
27,0\end{array}$ & & & & $\begin{array}{l}0,20- \\
0,60\end{array}$ & & $\begin{array}{c}0,15- \\
0,35 \\
\end{array}$ & & \\
\hline $\begin{array}{l}\text { NiCr23Co12Mo } \\
\text { (Alloy 617) }\end{array}$ & $\begin{array}{c}\max \\
2,0\end{array}$ & $\mathrm{Bal}$ & $\begin{array}{l}20,0- \\
23,0\end{array}$ & $\begin{array}{l}8,0- \\
10,0\end{array}$ & $\begin{array}{l}10,0- \\
13,0\end{array}$ & & & $\begin{array}{c}0,20- \\
0,50\end{array}$ & $\begin{array}{c}0,6- \\
1,5\end{array}$ & $\begin{array}{c}\max \\
0,7\end{array}$ & $\begin{array}{c}0,05- \\
0.10\end{array}$ \\
\hline
\end{tabular}

Complex non-destructive examinations and controlled analyses of the chemical compositions of the examined test pieces, which are compliant with the requirements assigned for martensite and austenitic steels, have been performed on the base of parents material requirements and RAFAKO S.A. experience. The scope of examinations included the correctness/ accuracy of welding and heat treatment processes by the analysis of: the steel immediate strength properties, technological properties of the welded joints, creep test results, structure stability and properties assessment as the result of the timely influence of the temperature, the level of which corresponds to the operating temperature of a boiler in operation (i.e. the assessment of resistance to ageing process).

With such preparation of test pieces, the specific microstructure and examinations are being carried out at the Institute for Ferrous Metallurgy in Gliwice, with the objective to evaluate their properties and structure, as well as the behaviour of the materials and welded joints in the room and operational conditions $[2,3]$.

\section{Welding and Heat Treatment Processes of Similar Martensite and Dissimilar Martensite to Austenitic Steels}

In the welding process for those steels, it has been assumed that the chemical composition of the welding consumables of similar martensite materials, shall be similar to those of the base materials. With the purpose to weld the root bead on the coil tubes, have been implemented GTAW method, and the same technique for welding the other filling passes. Martensitic steels containing $9 \% \mathrm{Cr}$, such as P91, P92, are characterised by relatively high temperature at the beginning of the martensitic process $\mathrm{M}_{\mathrm{s}}$, which is approx. $400^{\circ} \mathrm{C}$. So where steels containing $9 \% \mathrm{Cr}$ are welded in the temperature range of martensite occurrence, i.e. between 200 and $350^{\circ} \mathrm{C}$, as a result of welding a strapped martensite structure is formed, with effects of self-tempering.

The martensitic steels containing $12 \% \mathrm{Cr}$ produce considerably more difficulties in order to master the welding technology. This concerns, in particular, X12CrCoWVNb12-2-2 (VM12) steel, which contains tungsten and cobalt additions. The cooling rate $t_{8 / 5}$, as well as the cooling temperature after welding of those steels should be selected in such a way so as to assure full martensitic transformation, i.e. it shall be finished at a temperature below $\mathrm{M}_{\mathrm{f}}$. Following welding, all welded joints undergo stress relief annealing at the temperature range from 740 to $780^{\circ} \mathrm{C}$. Additionally, the welded joints of superheater coils have undergone the required non-destructive examinations, the evaluation of the mechanical properties, technological properties and examinations of welded joints' structure, in the scope of base material, HAZ and welds metal, in compliance with the requirements of EN 15614-1.

The complies of steel grades, them dimensions, the welding method and recommended welding consumables for connection of austenitic steel, grades of Super $304 \mathrm{H}$ and HR3C, were indicated in Table 3. 
Table 3. Complies of steel grades, dimensions, the welding method and recommended welding consumables for joints of Super 304H and HR3C steels

\begin{tabular}{|c|c|c|c|c|}
\hline Item & Grade of materials & Dimensions & $\begin{array}{c}\text { Welding } \\
\text { method }\end{array}$ & Consumables \\
\hline 1 & Super 304H+Super 304H & $\varnothing 42,4 \times 5,6$ & 141 & NIBAS 625 -IG \\
\hline 2 & HR3C + HR3C & $\varnothing 51 \times 4,5$ & 141 & NIBAS 625 -IG \\
\hline
\end{tabular}

\section{The Specific Test Results. Temperature Influence on Impact Energy}

Because of limited scope, only the selected reseals of examination are present in this paper.

The comparison of impact energy test results, measured on specimens with a V-notch, has been made for base material of steam superheater components within the temperature range from "_"100 to $60^{\circ} \mathrm{C}$. The impact transition temperature level, into brittle condition has been presented on billow drawing: i.e. approx. "“-" $100^{\circ} \mathrm{C}$ for steel X10CrWMoVNb9-2 (P92) and only approx. "_" $20^{\circ} \mathrm{C}$ for steel X12CrCoWVNb12-2-2(VM12).

The selected test results of steels X10CrWMoVNb9-2 (P92) and X12CrCoWVNb12-2-2(VM12) are shown in Figure 1.

a)

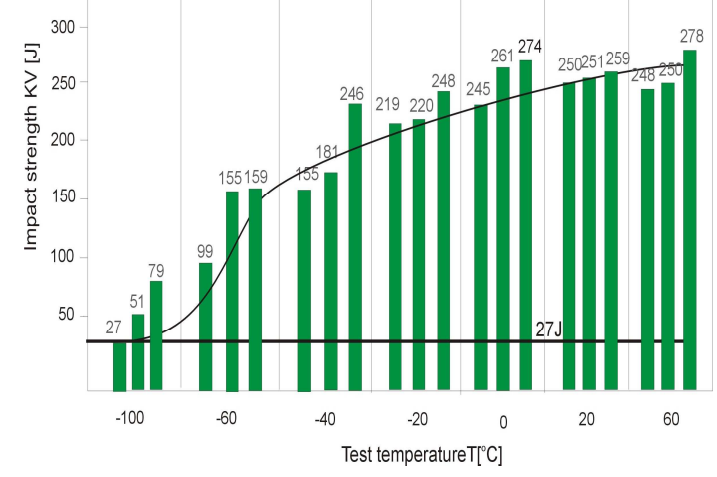

b)

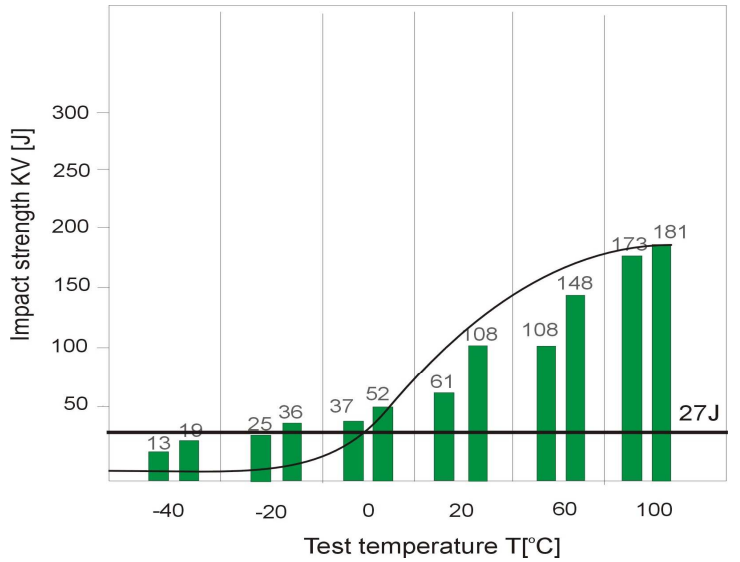

Figure 1. Comparison of impact transition temperature, as measured on specimens with a V-notch, depending on test temperature, within the range from "-_" $100^{\circ} \mathrm{C}$ to $100^{\circ} \mathrm{C}$, on base material of steam superheater outlet header specimens, made of steel:
a) X10CrWMoVNb9-2 (P92),
b) X12CrCoWVNb12-2-2(VM12)

\section{Comparison of Base Material and Welded Joints Hardness and Structure Results}

The structure examinations have been performed with a transmission electron microscope and scanning electron microscope, at magnifications up to 800 and to 5,000x, respectively. Observations have been carried out on transverse metallographic micro-sections of the material and circumferential welded joint of the fabricated steam superheater pieces.

Some obtained exemplary results of testing the structure of circumferential welded joints material, as observed in a scanning electron microscope at magnifications 2,000x, are shown in Figure 2. The base material structure, depending on the examined steel grade, is mainly tempered martensite, however, the steel containing $9 \% \mathrm{Cr}$, frequently with lower bainite and few ferrite areas (the hardness of the examined materials has ranged from approx. 200 to $240 \mathrm{HV} 10$ ).

The hardness measurements of the circumferential welded joints have been done on transverse metallographic micro-sections. The measurements have been taken: at close-to-surface zones, on the side of the weld face and the root pass, as well as in the centre of the component thickness. 
The structure of welded joints, which are most frequently observed in the HAZ, constitutes of martensite with some share of bainite, having the hardness from approx. 220 to 260 HV10, in case of steel X10CrWMoVNb9-2 (P92) steel, following welding and heat treatment. In case of $\mathrm{X} 12 \mathrm{CrCoWVNb} 12-2-2$ (VM12) steel, in the welded joints can observe the mixture of martensite with a small quantity of bainite [4]. Hardness of parent material, HAZ and welds metal, following welding and heat treatment, has not exceeded $300 \mathrm{HV} 10$, with the maximum difference being not higher than 50 HV10.

a) Microstructure of X10CrMoVNb9-1 (P91) steel

Parent Material

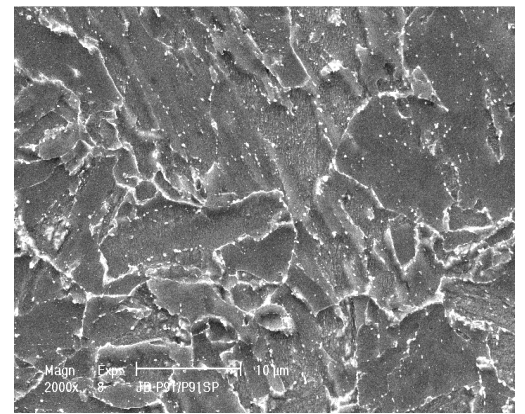

HAZ

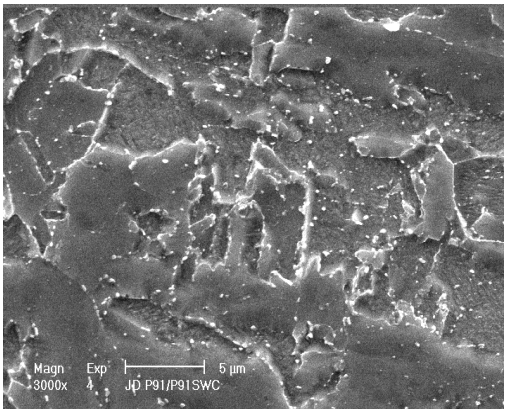

Welds Metal

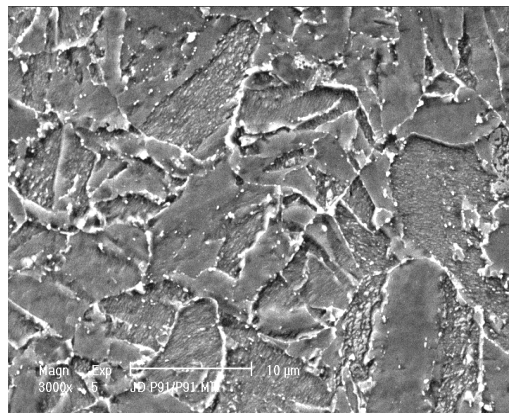

b)

Microstructure of X12CrCoWVNb12-2-2 (VM12) steel


Figure 2. Microstructure comparison of circumferential welded joints elements:

parent material, HAZ and welds metal of steam superheater, as detected by means of SEM, made of steels: a) X10CrMoVNb9-1 (P91),

b) X12CrCoWVNb12-2-2 (VM12)

\section{Qualitative Assessment of Thin-Walled Tube Steam Superheater and Stub Welded Joints}

Within the undertaken programme of implementation of new austenitic steels as Super304H and HR3C, welded joints of outlet steam superheater components were performed of tubes $\varnothing 42,4 \times 5,6$ and $\varnothing 51 \times 4.5 \mathrm{~mm}$ at the boiler maker area. The research programme included fabrication of similar and dissimilar welded joints, including those made of steels HR3C+HR3C, HR3C+T91, HR3C+VM12 and T91+Super304H. The evaluation of correctness of the welded joints fabrication technology has been made on the basis of standard EN-ISO 15614-1 requirements.

The carried out bending tests, in accordance with standard PN-EN 910 - for two test specimens were achieved bending angle is equal to $180^{\circ}$, without detection of defects on the tensile surface. The hardness of the fabricated welded joints does not exceed $260 \mathrm{HV}$ and that of the heat-affected zone is $290 \mathrm{HV}$. Selected of parent material structures, welded joints and heat-affected zone, as obtained on a light scanning microscope, are presented in Figure 3. 


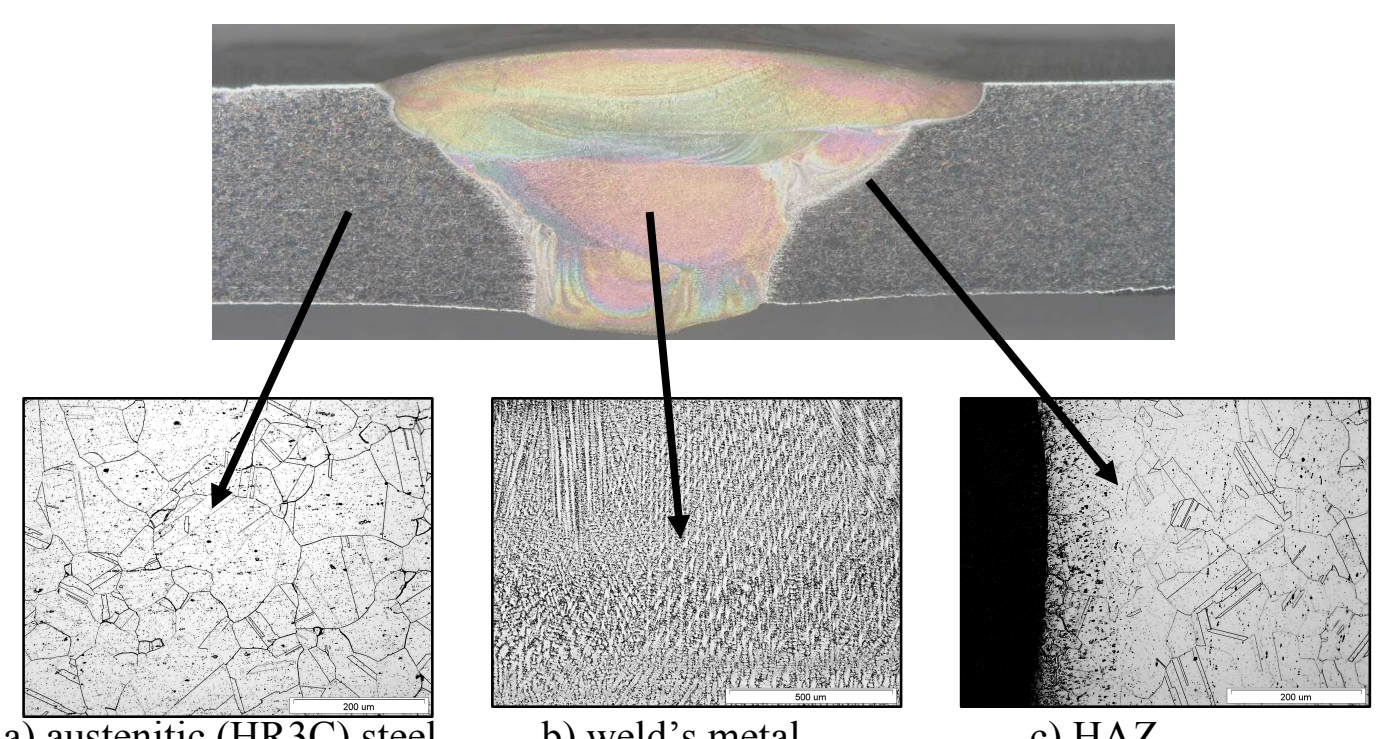

a) austenitic (HR3C) steel

b) weld's metal

c) HAZ

Figure 3. Macro and micro-structure of welded joint made of $\mathrm{HR} 3 \mathrm{C}$, observed in the area of austenitic (HR3C) steel, weld's metal and HAZ.

\section{Conclusions}

1. The impact energy for the similar circumferential welded joint material, at room temperature (with regard to the HAZ and weld's metal), is comparable to the base material results.

2. The impact transition temperature into brittle condition for the base material, i.e. steel $\mathrm{X} 10 \mathrm{CrMoVNb} 9-1$ (P91), is "_." $100^{\circ} \mathrm{C}$, whereas, for that made of steel X12CrCoWVNb12-2-2 (VM12), the transition temperature is "-" $20^{\circ} \mathrm{C}$. As regards the base material of steel $\mathrm{X} 10 \mathrm{CrWMoVNb} 9-2$ (P92), this temperature is an intermediate one in comparison with those made of the other steel grades.

3. In the steel containing $9 \% \mathrm{Cr}$, frequently with lower bainite and few ferrite areas, the hardness of the examined materials has ranged from approx. 200 to 240 HV10. A considerable increasing in hardness, i.e. by approx. 50HV, has been observed in case of X12CrCoWVNb12-2-2 (VM12) steel.

4. The changes in the microstructure, resulting from the influence of temperature 600 and $650^{\circ} \mathrm{C}$, as well as time up to 10,000 hours, have to be described as substantial. We have observed a slow disintegration of martenisite by means of the initiated process of decay the martensite straps, with the simultaneous formation of sub-grains.

\section{References}

[1] Hernas A., Dobrzański J.: Trwałość i niszczenie elementów kotłów i turbin parowych. Wyd. Politechniki Śl., Gliwice, 2003 (in polish only).

[2] Maciosowski A., Dobrzański J., Zieliński A.: Mechanical and creep testing of new steel and welds for critical elements of friendly Power Plant. Report No2 SPB/COST/96/2006. Cost 536, Gliwice 2006, Poland.

[3] MaciosowskiA., Dobrzański J., Zieliński A.: Mechanical and creep testing of new steel and welds for critical elements of friendly Power Plant. Report No3 SPB/COST/96/2006. Cost 536, Gliwice 2007, Poland.

[4] Gabrel J., Bendick W., Vanderberghe B., Lefabrre B: "Status of development of the VM12 steel for tubular applications in advanced power plants". $8^{\text {th }}$ Int. Conf. on Materials for Advanced Power Engineering 2006, Liege, Belgium. ISBN 389336-436-6, Forschungszentrum Jülich 2006, p.1065.

[5] Dobrzański J., Pasternak J.: Properties and application of welded joints in heat resisting bainitic and martensitic steels. 25 International Conference "Welding 2008", 406, p. 137.Subotica, Serbia, 4-6 Jul 2008. 